\title{
The Determinants of Corporate Dividend Policy in Pakistan
}

\author{
Aliya Bushra* and Nawazish Mirza**
}

\begin{abstract}
The objective of this study is to identify the significant determinants of firms' dividend policy across different sectors in Pakistan. Using data on 75 companies listed on the KSE 100 index for the period 2005 to 2010, we find that profitable firms tend to give higher dividends than loss-making firms. Firm size has a negative relationship with the dividend payout ratio and dividend yield, indicating that, the larger the firm, the more likely it is to retain cash to pay off its liabilities. Growth in sales is positively related to dividend yield, whereby an increase in sales leads to higher profitability and higher dividend payments. Ownership concentrated within institutions (such as banks and insurance companies), the management/family, and individuals has a negative impact on the payout ratio. Institutional owners are more likely to retain excess cash and thus omit dividends, individual owners prefer capital gains to dividends given the tax deduction, and management- or family-owned firms avoid dividends, which lead to increased agency problems. Finally, the market-to-book ratio is negative and highly significant: firms with better growth opportunities rely on internal financing more than on generating external funds.
\end{abstract}

Keywords: Market to book, market cap, dividend payout, ownership structure, Pakistan.

JEL classification: G30, G32, G35.

\section{Introduction}

Dividends are rewards given to investors for their investment in a firm and these rewards can take the form of cash (cash dividends) or stock (stock dividends), depending on the company's policy. These dividends are important to investors because they provide a measure of certainty concerning the company's financial wellbeing. The growth in business also ensures a stable and smooth dividend payout in the future for these firms (Lintner, 1956).

\footnotetext{
* Assistant Professor, Lahore School of Economics, Pakistan.

** Associate Professor (Finance), Centre for Research in Economics and Business, Lahore School of Economics, Pakistan.
} 
Dividends provide information or "signals" to the market concerning the company's future performance. A dividend cut, for example, immediately signals that the firm is retaining its free cash flow (FCF) for future expansion or that it is uncertain about its future earnings and thus avoiding dividend payouts. Signaling theory argues that managers cannot cut or increase the dividend rate arbitrarily because omitting dividends sends out negative signals to the market (Bhattacharya, 1980).

Jensen's (1986) hypothesis states that any FCF should be distributed among shareholders to reduce agency cost. Rozeff (1982) argues that dividends also provide the indirect benefit of control in the case of FCFs ${ }^{1}$ where shareholders do not actively monitor the firm's management. However, the company should not reject positive net present value (NPV) projects simply because it may have to pay dividends or decrease the agency cost; otherwise, future dividend payouts cannot be maintained. Instead, the firm should try to pay dividends while maintaining sufficient retained earnings in order to avoid raising new funds for business expansion. Dividend payments should not be funded through borrowing because this can prove costly for the firm because by doing so, the firm's debt-equity ratio will worsen, eventually affecting its share prices.

Dividends are also irrelevant when firms rely on their own finances for projects (in the absence of a tax system) (see Miller \& Modigliani, 1961, who describe irrelevance in the presence of taxes). ${ }^{2}$ Modigliani and Miller (1958) show that firm value is independent of dividend policy: investors do not care about a company's dividend policy because they can buy shares and borrow against them. Thus, in the case of no taxes or bankruptcy costs, dividend policy becomes irrelevant.

\section{Research Rationale}

This paper is based on the following rationale: First, with Pakistan's capital market growing and the economy improving, it would be interesting to find out which factors play an important role in developing and evaluating firms' dividend policy. The insights drawn could help both managers and investors better understand a company's prospects. Managers would also have a clearer view of investors' expectations and

\footnotetext{
${ }^{1}$ FCFs measure financial performance or valuation calculated as the operational cash flow minus capital expenditure. The FCF represents the cash a company is able to generate after laying out the money required to maintain or expand its asset base.

${ }^{2}$ Miller and Modigliani (1958) posit that dividends are irrelevant when firms finance their projects (in the absence of a tax system). Miller and Scholes (1978) describe irrelevance in the presence of taxes.
} 
design firm policies so as to serve current investors better while attracting new investors.

Second, Pakistan's tax system is different from that of developed markets in that a 10 percent withholding tax is deducted from dividend income. Moreover, unless a firm announces its dividends for a particular year, even if it has made a profit, it is liable to pay a 35 percent corporate income tax. Dividends are subject to double taxation, which is why most investors initially relied on capital gains (for tax exemption). ${ }^{3}$ In 2010, however, a capital gains tax on stocks was levied, but not implemented until the fiscal year 2011.4 This rule does not apply to our study because the sample period is limited to 2005-10, for which the assumption that capital gains are tax-exempt holds true. The possibility of differences in the tax system can influence dividend policy.

Third, the payment of dividends depends on company policy and its financial position. There are no specific rules in Pakistan that make dividend payments mandatory. This can raise the agency problem because managers may decide to omit dividend payments and invest these FCFs in low-cost capital projects. This is done to serve their own interests because managers are often evaluated on the basis of the firm's annual sales growth.

Finally, Pakistan's financial market is greatly influenced by the agency problem because of weak corporate governance arising from ownership structures. Most Pakistani firms have one primary owner who holds majority shares in the affiliated firms. This influences dividend policy, creating an agency problem between the minority shareholders and majority owners. Pakistani firms are often family-owned and liable to ignore outsider or minority interests associated with payouts, which eventually leads to a conflict. This factor affects the firm's dividendsmoothing behavior in the capital market.

\section{Literature Survey on Corporate Dividends Policy}

Gill, Biger, Mand, and Shah (2012) compare the determinants of dividend policy in the US manufacturing and services sector. Their results show that payouts in the services industry depend on profit margins, sales growth, and debt-equity ratios. However, for manufacturing firms, payouts are a function of profit margins, market-to-book ratios, and tax implications.

\footnotetext{
${ }^{3}$ Ahmad and Javid (2009) present evidence for this as does the Federal Board of Revenue website.

${ }^{4}$ The government extended this to 2010 such that no capital gains tax was collected on stocks in Pakistan prior to 2010 .
} 
Denis and Osobov (2008) analyze dividend polices in different countries over 1989 to 2002. In the US, Canada, UK, Germany, France, and Japan, larger and more profitable firms are more likely to pay higher dividends. Outside the US, however, there is little evidence of a positive relationship between dividend paying and nonpaying firms. Renneboog and Szilagyi (2008) compare European firms paying lower dividends with marketoriented American firms. They find that the payouts of Dutch firms were lower because they tended to use their power against shareholder provisions.

Baker and Wurgler's (2004) catering theory suggests that the firm's managers should give incentives to its shareholders according to their demands. They should cater to investors in their best interest by paying out smooth dividends when the latter puts a premium on dividend-paying firms and by not paying out dividends when investors prefer nonpaying firms. Skinner and Soltes (2011) investigate payout policies with respect to earnings quality, which does not change over time. Their sample consists of all firms listed on the NYSE (except utilities and financial firms) between 1974 and 2005. Their paper finds that firms that were paying dividends were less likely to report losses: investors tended to invest in those firms that showed a regular pattern of giving dividends.

This leads to information asymmetry, which, as DeAngelo, DeAngelo, and Skinner (2008) argue, implies the need to distribute FCF. Their results suggest that agency costs and security valuation problems are explained well by the main features of payout policies, using Lintner's (1956) model. Another cost involved is agency cost and DeAngelo and DeAngelo (2006) use a sample of 22 large private firms to show how dividend payments can prevent significant agency problems - firms with relatively high retained earnings are more likely to pay dividends. They test this on publicly traded industrial firms; the results between the payment of dividends and the ratio of retained earnings are highly significant.

Khang and King (2006) examine the implications of asymmetric information and find that firm insiders take informational advantage in trading shares. This affects the firm's dividend policy. Using a sample of companies for 1982-95, they find that, the higher a firm's dividends, the lower will be insider gains.

Dividends also involve large costs in terms of premium tax, the cost of risk, and opportunity cost. Cohen and Yagil (2008) address the negative relationship between the expected dividend per share (DPS) and the ratio of information on the cost of the dividend held by "category" investors and 
arbitrageurs. Their results imply that dividends depend on their shortterm and long-term impact on stock prices as well as on financial leverage and investment opportunities.

Farinha (2003) analyzes the agency problem of corporate dividend policy in the UK. His findings suggest that paying shareholders in cash helps reduce the agency problem in two ways: (i) by increasing external capital or (ii) by reducing the FCF. Based on data for two five-year periods (1987-91 and 1992-96) for a sample of 600 firms, he finds a strong relationship between dividend payouts and insider ownership in the UK.

Faulkender and Wang (2006) test the marginal value of corporate cash holdings that arises from the difference in dividend policy. By examining the variations in stock returns, the study finds that cash values decline with higher leverage so that firms choose cash distribution to repurchase stocks. The data is analyzed using semi-quantitative predictions of cross-sectional variations.

Kumar (2006) examines the possible relationship between ownership structure, corporate governance, and dividend payout policy in India's emerging market. Based on a sample of 2,575 firms listed between 1994 and 2000, the results show that ownership is a significant variable in determining firms' dividend policy. Institutional owners are found to have an inverse relationship with dividends and no evidence is found in favor of foreign ownership and dividend payout growth.

In the context of Pakistan, Imran (2011) tests the determinants of dividend payouts for a sample of 36 engineering firms from 1996 to 2008. The results show that the size of the firm, earnings per share, cash flow, ownership structure, and previous DPS all have a significant impact on dividend payouts in this sector.

Afza and Mirza (2011) test the impact of institutional shareholding on corporate dividend policy for 120 companies over the period 2002 to 2007. Their results indicate a positive relationship between institutional ownership and return on equity (ROE), and a negative relationship with sales growth. In an earlier study, Afza and Mirza (2010) test the impact of ownership structure and cash flow on corporate dividend policy, based on a sample of 100 firms listed on the Karachi Stock Exchange (KSE) during 2005-07. Their results show that managerial and individual ownership, cash sensitivity, firm size, and leverage are negatively related to cash dividends. 
Ahmad and Javid (2009) find that profitable firms pay larger dividends than small firms, and that leverage and growth opportunity have a negative relationship with dividend payouts. These results hold for a sample of nonfinancial firms listed on the KSE from 2001 to 2006. However, when Ahmad and Javid (2010) test for ownership structure using the same data, they find that concentration within the management and individuals has a negative impact on dividend payouts.

Nazir, Nawaz, Anwar, and Ahmed (2010) investigate the role of dividend policy in determining the volatility of stock prices in Pakistan. The study applies fixed effects and random effects to panel data for a sample of 73 firms listed on the KSE for the period 2003-08. The results imply that dividend policy has a strong, significant relationship with stock price volatility in the KSE.

Finally, Asghar, Shah, Hamid, and Suleman (2011) attempt to determine the impact of dividend payouts on stock prices. They use data for a sample of nonfinancial firms across five sectors (chemicals, cement, sugar, engineering, and synthetic fibers) for the period 2005-09. The results show that dividend payouts and dividend yield are significantly and positively correlated with price volatility and firm size.

\section{Research Methodology}

This paper explores the main factors influencing dividend policies among nonfinancial firms in Pakistan. The sample includes all profitable firms that were paying dividends during 2005-10. Firms that had incurred losses, i.e., whose net income was negative, during the sample period were excluded. Also, all those nonfinancial firms that had not missed a single dividend payment over the entire sample period were also included.

In general, dividend-paying firms are those that are transitioning from growth to maturity, where the payment of dividends is a unique feature of the business cycle. This is because mature firms have access to fewer positive NPV projects and ample cash reserves, which makes distribution desirable for financial managers. It also makes dividends sticky, while frequent changes in payout send a negative signal to investors (see Myers \& Majluf, 1984; Damodaran, 1989; Moyen, 2004). Therefore, to assess the determinants of dividend payments from firm fundamentals, it is critical to discriminate between firms that pay dividends and those that do not. Otherwise, the results will be biased toward the firm's lifecycle. 
Finally, Pakistan is unique in that firms' retained earnings are also taxed, pushing more companies into paying dividends as early as possible. This underscores the need to distinguish between dividend-paying and nonpaying firms. We take into account the total sum paid to shareholders as either cash dividends or stock dividends.

Our sample consists of 75 nonfinancial companies listed on the KSE 100 index. The main data was collected through companies' annual reports for 2005-10, with a total of 450 observations. We run a fixed effects regression model on the panel data.

\subsection{Dependent and Independent Variables}

The two dependent variables are dividend yield and the dividend payout ratio. The dividend yield is the amount of DPS according to the firm's average price. The average price of the stock is calculated based on its price at the beginning of the year and at the end. This formula allows us to test investors' perceptions and expectations concerning the firm's share value. The DPS is the return a shareholder earns on one share. Dividend yield indicates how much a firm will pay in dividends (cash or stock) as a percentage of its shareholders' investment over the course of a year. Thus, it measures how much cash flow an investor receives for each dollar invested in an equity position.

The dividend yield is estimated as follows:

$$
D Y=\frac{D P S_{t}}{P_{\text {avg, } t}}
$$

where $D Y_{t}$ is the dividend yield of a firm at the end of year $t$, DPS is the dividend per share (cash or stock dividend or both), and $P_{\text {avg, } t}$ is the average price of a firm's stock after dividends are announced at time $t$.

The second dependent variable is the dividend payout ratio, calculated as the ratio of total dividends paid to shareholders to the firm's net earnings (profits). This variable tests the impact of the firm's characteristics when making a financial decision, and highlights the relationship between net income and dividend payments to shareholders. The dividend payout ratio is estimated as follows:

$$
P Y_{t}=\frac{\operatorname{Div}_{t}}{N I_{t}}
$$


where $P Y_{t}$ is the payout ratio at the end of year $t, D i v_{t}$ represents the total dividends (both cash and stock dividends) paid to shareholders, and $N I_{t}$ is the firm's net income at time $t$. This variable helps determine the amount of dividends, whether cash or stock dividends or both, paid to shareholders according to the firm's net income. Since loss-making firms are excluded from the sample, the variable checks the impact of dividend payments made by profitable firms. The payout ratio is sensitive to profitability and dividend yield is sensitive to changes in share prices. Dividend yield indicates the rate of return in the form of cash dividends paid to shareholders, but the dividend payout ratio shows how much of a company's net earnings are paid out as dividends.

The first independent variable is the market-to-book (M/B) ratio, which is most commonly used to test the growth opportunity available to a firm. It has a negative effect on both dependent variables because larger companies with a higher $\mathrm{M} / \mathrm{B}$ ratio tend to pay lower dividends. The greater the investment opportunity available to the firm, the more retained earnings it will need to avail the opportunity. "Growth" firms, therefore, pay their shareholders smaller dividends. Most such firms rely on internal financing in order to avoid the high cost associated with external financing. The ratio is written as:

$$
M B V_{t}=\frac{M V \text { of equity }}{B V \text { of equity }}
$$

where $M B V_{t}$ is the ratio of the market-to-book value of equity in period $t$. The market value of equity is calculated by multiplying the number of shares outstanding into the market price (taken from the KSE website). The book value of equity is taken as the total equity presented in the firm's balance sheet at the end of year $t$.

The second independent variable is ownership structure, the first category of which includes shares held by institutional investors such as banks and insurance companies. Institutional owners are expected to have a negative effect on both dependent variables mainly because such firms tend to pay dividends in order to reduce the cost of agency conflict. This is similar to the FCF hypothesis, which states that any FCF in the hands of the management should be distributed among shareholders to reduce agency cost (Jensen, 1986; Rozeff, 1982). Highly concentrated institutional ownership, such as shares held by banks, has a negative effect on dividend payouts (Renneboog \& Szilagyi, 2008) due to the securitization of a bank's debts (loans). Most banks invest their FCF in different types of assets to secure their financial obligations and maintain their financial position in 
the market (Al-Malkawi, 2007). As a result, such institutions discourage dividend payments (Afza \& Mirza, 2011).

The second category of ownership structure includes insider owners - family-owned firms or majority shares held by the management. This has an inverse impact on the dividend payout ratio (Afza \& Mirza, 2010). Family members are heavily compensated in the form of high salaries, which increases the firm's expenses such that its net earnings are too low (or even negative) to pay out any dividends (Afza \& Mirza, 2011). Another reason for this negative relationship is that managers are reluctant to distribute cash to shareholders (Jensen, 1986), preferring to keep these FCFs to meet their own interests (such as investing in negative NPV projects in order to gain fringe benefits).

The third category of ownership structure comprises shares held by individual investors categorized as agents or brokers or retired civilian officers. This variable usually has a negative effect on dividend yield and the payout ratio (Asghar et al., 2011), mainly due to tax treatment (Miller \& Modigliani, 1961). Individuals are more interested in capital gains than in dividends because the former are tax-exempt while dividends are subject to double taxation (Miller \& Scholes, 1978).

As mentioned earlier, Pakistan's tax system is different from that of developed markets: a 10 percent withholding tax is deducted from dividend income and a 35 percent corporate income tax is levied on firms that do not announce their dividends for a particular year. Since dividends are subject to double taxation, investors tend to rely on capital gains, which are tax-exempt (for the study period). Investors' low preference for dividend payouts means that a higher proportion of individual investors among the firm's shareholders will have a negative relationship with the dividend payout and with dividend yield.

So, ownership structure is estimated as the number of majority shareholders (taken from firms' annual reports). This comprises the proportion of shares held by (i) institutional investors (banks, pension funds, mutual funds, insurance companies, foreign companies, and investment firms), (ii) family members or the firm's management, and (iii) individual investors (agents, dealers, and retired civilians).

The third independent variable is firm size, which is likely to have a negative effect on dividend yield and dividend payout. Larger firms have greater liabilities and thus retain their excess cash (Lintner, 1956). Nasir et 
al. (2010) find that the size of a firm is positively related to the dividend payout ratio: the larger the firm, the more stable its operations cash flow will be and the more likely that it will pay dividends to its shareholders. Another reason is that larger companies are more diversified and need to maintain a reputation of financial wellbeing in the market by paying out smooth dividends to their investors (Asghar et al., 2011). Thus, large firms tend to pay more dividends to their shareholders rather than investing in assets. Firm size is measured as the logarithm of total assets:

$$
S Z_{t}=\log (T A)_{t}
$$

where $S Z_{t}$ is the size of the firm at time $t$ and $\log (T A)_{t}$ is the logarithm of total assets at time $t$. By taking the logarithm, we eliminate any variations (outliers) present in the data.

The fourth independent variable is sales growth. Afza and Mirza (2011) establish a positive relationship between sales growth and dividend payouts. They find that firms able to generate sales are more likely to reward their shareholders. This variable has both a positive as well as negative relationship with dividend yield and the payout ratio. Sales growth is measured as the percentage change in sales:

$$
S G_{t}=\frac{C S_{t-1}-P S_{t-1}}{P S_{t-1}}
$$

where $S G_{t}$ represents sales growth at time $t$, and $C S_{t}$ and $P S_{t-1}$ are current sales at time $t$ and previous sales at time $t-1$, respectively.

The fifth independent variable is financial leverage, which usually has a negative relationship with dividend payout as well as with dividend yield. Generally, firms with higher leverage try to increase their retained earnings in order to decrease their dependency on external financing. Such firms pay lower dividends to avoid the cost of raising external capital (see Rozeff, 1982; Jensen, 1986), where they would have to pay a fixed financial charge and interest, and repay the principal amount; firms that were unable to repay their debts would end up liquidating their assets. In order to maintain their liquidity position and cash flow, highly leveraged firms avoid making dividend payments. Financial leverage is measured as:

$$
L E V_{t}=\frac{T L_{t}}{T A_{t}}
$$


where $L E V_{t}$ is total leverage estimated at time $t$, and $T A_{t}$ and $T L_{t}$ are total assets and total debt in period $t$, respectively.

The two independent variables used as determinants of dividend policy are Return on Assets (ROA) and Return on Equity (ROE). These profitability ratios have a positive impact on both dependent variables (dividend yield and dividend payout ratio). Firms with positive earnings tend to pay higher dividends and firms with higher profitability have stable earnings over time and can easily afford to distribute large FCFs as dividends. Thus, we expect ROE and ROA to be positively related to dividend yield and the dividend payout ratio.

The profitability ratios are estimated as follows:

$$
\begin{aligned}
& R O A_{t}=\frac{N I_{t}}{T A_{t}} \\
& R O E_{t}=\frac{N I_{t}}{O E_{t}}
\end{aligned}
$$

where $R O A_{t}$ and $R O E_{t}$ are the firm's return on assets and return on equity at time $t$, respectively. $N I_{t}, O E_{t}$, and $T A_{t}$ are the firm's net income, total owners' equity, and total assets in period $t$, respectively.

\subsection{Model 1}

In the first model, all the independent variables are tested against dividend yield (with fixed effects). These variables test the impact of the profitability ratios, growth opportunity ratios, such as the $\mathrm{M} / \mathrm{B}$ ratio and sales growth, leverage, firm size, and ownership concentration on dividend yield. The following regression model (with fixed effects) is applied to the panel data:

$$
\begin{aligned}
& D Y_{i t}=\beta_{0}+\beta_{1 t} O W N_{i n s t, i t}+\beta_{2 t} O W N_{f, i t}+\beta_{3 t} O W N_{i d v, i t}+\beta_{4 t} L E V_{i t}+ \\
& \beta_{5 t} S G_{i t}+\beta_{6 t} R O E_{i t}+\beta_{7 t} R O A_{i t}+\beta_{8 t} M B V_{i t}+\beta_{9 t} \log (T A)_{i t}+ \\
& \beta_{10 t}\left\{\log (T A)_{i t}\right\}^{2}+\beta_{11 t}\left\{O W N_{i n s t, i t}\right\}^{2}+\beta_{12 t}\left\{O W N_{i d v, i t}\right\}^{2}+ \\
& \beta_{13 t}\left\{O W N_{f, i t}\right\}^{2}+\varepsilon_{i t} \\
& t=1,2,3 \ldots 6(2005 \text { to 2010) }
\end{aligned}
$$

DY is the dividend yield at time $t$, SG is sales growth, and OWN is ownership structure where $O W N_{\text {inst }}$ is the ownership concentration held 
by institutional investors at time $t, O W N_{f}$ is the ownership concentration held by the family or management, and $O W N_{i d v}$ is the ownership concentration held by individual investors at time $t$. MBV is the $\mathrm{M} / \mathrm{B}$ ratio, $\mathrm{SZ}$ is the log of total assets representing firm size at time $t, \mathrm{LEV}$ is the leverage or total debt held by the firm, and ROA and ROE are the profitability ratios. The model also includes the square terms of size and ownership (institutional, family, and individual).

\subsection{Model 2 (Fixed Effects)}

The second model tests the significance of the independent variables against the dividend payout ratio (with fixed effects):

$$
\begin{aligned}
& P Y_{i t}=\beta_{0}+\beta_{1 t} O W N_{i n s t, i t}+\beta_{2 t} O W N_{f, i t}+\beta_{3 t} O W N_{i d v, i t}+\beta_{4 t} L E V_{i t}+ \\
& \beta_{5 t} S G_{i t}+\beta_{6 t} R O E_{i t}+\beta_{7 t} R O A_{i t}+\beta_{8 t} M B V_{i t}+\beta_{9 t} \log (T A)_{i t}+ \\
& \beta_{10 t}\left\{\log (T A)_{i t}\right\}^{2}+\beta_{11 t}\left\{O W N_{\text {inst }, i t}\right\}^{2}+\beta_{12 t}\left\{O W N_{i d v, i t}\right\}^{2}+ \\
& \beta_{13 t}\left\{O W N_{f, i t}\right\}^{2}+\varepsilon_{i t} \\
& t=1,2,3 \ldots 6(2005 \text { to 2010) }
\end{aligned}
$$

PY is the dividend payout at time $t$, SG is sales growth, and OWN is ownership structure where $O W N_{\text {inst }}$ is the ownership concentration held by institutional investors at time $t, O W N_{f}$ is the ownership concentration held by the family or management, and $O W N_{i d v}$ is the ownership concentration held by individual investors at time $t$. MBV is the $\mathrm{M} / \mathrm{B}$ ratio, $\mathrm{SZ}$ is the log of total assets representing firm size at time $t, \mathrm{LEV}$ is the leverage or total debt held by the firm, and ROA and ROE are the profitability ratios. The model also includes the square terms of size and ownership (institutional, family, and individual).

\section{Empirical Results and Analysis}

Table 1 reports descriptive statistics (including the mean and standard deviation) for all the variables described in Section 4 for the period 2005-10. We see that the dividend yield follows a stable trend while there is a slight increase in the payout ratio. Financial leverage, ownership structure, and growth opportunity ratios are stable over time. This may be because industry was stable overall during this period, with no expansion having taken place due to the ongoing recession. The overall trends of central tendency and dispersion show that the dividend yield increases from 2005 to 2008. 
Table 1: Descriptive statistics, 2005-10

\begin{tabular}{lcc}
\hline Variable & Mean & Standard deviation \\
\hline $\mathrm{DY}$ & 0.06 & 0.14 \\
$\mathrm{PY}$ & 0.70 & 3.85 \\
$\mathrm{ROA}$ & 0.08 & 0.46 \\
$\mathrm{ROE}$ & 0.19 & 0.55 \\
$\mathrm{LEV}$ & 0.52 & 0.22 \\
$\mathrm{SG}$ & 0.27 & 0.56 \\
$\mathrm{MBV}$ & 1.70 & 2.15 \\
$\mathrm{SZ}$ & 7.62 & 1.42 \\
$\mathrm{OWN}$ & 0.49 & 0.26 \\
$\mathrm{OWN}_{\mathrm{idv}}$ & 0.17 & 0.12 \\
$\mathrm{OWN}_{\mathrm{f}}$ & 0.34 & 0.27 \\
\hline
\end{tabular}

Note: $\mathrm{N}=450$.

Source: Authors' calculations.

The payout ratio, ROA, firm size, and the $\mathrm{M} / \mathrm{B}$ ratio follow a decreasing trend for one year, after which they remain fairly stable throughout the sample period. Financial leverage clearly shows a downward trend, which means that most firms were able to repay their debt over this time. ROE shows a positive trend throughout the period.

Table 2 gives the results of the fixed effects (panel data) regression analysis of the profitability ratios, growth opportunity, firm size, financial leverage, and ownership structure vis-à-vis dividend yield. The empirical results reveal a strong relationship between the size of the firm, its profitability, and sales growth. ROA and ROE have a positive and highly significant impact in determining dividend yield. The coefficients of these variables are positive, which shows that firms able to maintain their profits are more likely to pay out dividends to shareholders. 
Table 2: Regression model of dividend yield for panel data (fixed effects), 2005-10

\begin{tabular}{lcccl}
\hline Variable & $\boldsymbol{\beta}_{\boldsymbol{t}}$ & SE & $\boldsymbol{t}\left(\boldsymbol{\beta}_{\boldsymbol{t}}\right)$ & p-value \\
\hline$\beta_{0}$ & 0.200 & 0.19 & 1.04 & 0.30 \\
$\mathrm{OWN}_{\mathrm{i}}$ & -0.130 & 0.16 & -0.81 & 0.42 \\
$\mathrm{OWN}_{\mathrm{f}}$ & -0.100 & 0.13 & -0.74 & 0.46 \\
$\mathrm{OWN}_{\mathrm{idv}}$ & -0.110 & 0.15 & -0.72 & 0.47 \\
$\mathrm{LEV}$ & 0.004 & 0.02 & 0.19 & 0.85 \\
$\mathrm{SG}$ & 0.020 & 0.01 & 2.99 & $0.00^{* * *}$ \\
$\mathrm{ROE}$ & 0.020 & 0.00 & 5.05 & $0.00^{* * *}$ \\
$\mathrm{ROA}$ & 0.010 & 0.00 & 3.42 & $0.00^{* * *}$ \\
$\mathrm{MBV}$ & -0.004 & 0.01 & -0.77 & 0.44 \\
$\mathrm{SZ}$ & -0.040 & 0.00 & -2.04 & $0.01^{* * *}$ \\
SZ & 0.830 & 0.00 & 2.34 & $0.02^{* *}$ \\
$\mathrm{OWN}_{\mathrm{i}}{ }^{2}$ & 0.090 & 0.16 & 0.31 & 0.76 \\
$\mathrm{OWN}_{\mathrm{idv}}{ }^{2}$ & -0.120 & 0.32 & -0.88 & 0.37 \\
$\mathrm{OWN}_{\mathrm{f}}{ }^{2}$ & 0.180 & 0.14 & 0.79 & 0.43 \\
Adj. $^{2}$ & & & & \\
$\mathrm{DW}^{2}$ & 0.158 & & & \\
\hline
\end{tabular}

Note: ${ }^{* * *}=$ significant at $99 \%,{ }^{* *}=$ significant at $95 \%$.

Source: Authors' calculations.

A positive coefficient means that both the independent and dependent variables are moving in the same direction: If the firm is profitable, it is more likely to pay dividends. If the firm generates enough operating cash flows from its sales, it will earn a higher net income, which implies higher profitability and stable earnings over time. In turn, this allows the firm to afford a larger FCF to be distributed as dividends. Thus, only profitable firms can maintain their FCFs and disburse these in the form of dividends. This significance is tested at 99 percent; at a 1 percent level of significance, profitability ratios have a highly significant impact on dividend yield.

The impact of firm size is significant at 99 percent, but has a negative slope. The square term of size is also significant at 95 percent, indicating that, when making a decision regarding dividends, firms take their size into account. The negative coefficient indicates that, the larger the firm, the more likely it will retain cash flows to avoid any discrepancies. In Pakistan's case, large firms tend to have greater liabilities or extended 
operations than smaller firms. In order to secure their operations and cash flows, they invest more in assets. As the size of the firm increases (denoted here by its total assets), the less likely it will generate a dividend yield.

The impact of sales growth is positive and highly significant at 99 percent. This result implies that Pakistani firms that had the chance to expand their business and increase sales still managed to reward their shareholders. Most firms in the sample had stagnating sales prior to 2005, given the ongoing economic and political crisis. Between 2005 and 2010, however, many firms were able to increase their sales. In order to maintain their market reputation, firms need to increase and sustain their sales growth: only those that could were able to pay dividends to their shareholders. The significance of this variable clearly indicates the importance of the signaling effect. The higher its sales, the greater the firm's profitability, and the more likely that it will have enough cash available to distribute among shareholders.

Finally, the Durbin-Watson (DW) statistic (Table 2) is 1.35 (less than 2), which indicates the presence of positive serial correlation, i.e., the disturbances are serially correlated.

Table 3 presents the empirical results of the second model with fixed effects, which tests the independent variables (profitability ratios, firm size, growth ratio, ownership structure, and financial leverage) against dividend payout. The significant independent variables in the first model (dividend yield) are also highly significant in the second, barring sales growth. Profitability ratios, ROA, and ROE are highly significant at 99 percent. Their coefficients are positive, which suggests that, the more profitable a company, the greater its chances will be of dividend payouts. Firms that are certain about their present and future earnings tend to make dividend payouts to their shareholders to maintain a certain level of business confidence.

The impact of firm size is also highly significant with respect to dividend payouts at 99 percent. It has a negative slope, which indicates that larger firms are more likely to retain FCFs than to pay dividends. Thus, firms with more assets and extended operations are less likely to pay out dividends. Larger firms tend to need greater cash flows than smaller firms to maintain their extensive day-to-day operations. The squared term of size has no impact on the payout ratio. 
Table 3: Regression model of dividend payout for panel data (fixed effects), 2005-10

\begin{tabular}{|c|c|c|c|c|}
\hline Variable & $\boldsymbol{\beta}_{t}$ & SE & $\boldsymbol{t}\left(\boldsymbol{\beta}_{t}\right)$ & p-value \\
\hline$\beta_{0}$ & 3.190 & 8.30 & 0.38 & 0.46 \\
\hline $\mathrm{OWN}_{\mathrm{i}}$ & -1.780 & 0.55 & -3.23 & $0.00^{* * *}$ \\
\hline $\mathrm{OWN}_{\mathrm{f}}$ & -1.800 & 0.66 & -2.72 & $0.01^{* * *}$ \\
\hline $\mathrm{OWN}_{\mathrm{idv}}$ & -2.400 & 0.64 & -3.78 & $0.00^{* * *}$ \\
\hline LEV & -0.390 & 0.26 & -1.51 & 0.13 \\
\hline SG & 0.010 & 0.04 & 0.31 & 0.75 \\
\hline $\mathrm{ROE}$ & 0.090 & 0.01 & 7.73 & $0.00^{* * *}$ \\
\hline ROA & 0.100 & 0.01 & 17.07 & $0.00^{* * *}$ \\
\hline MBV & -0.040 & 0.00 & -9.01 & $0.00^{* * *}$ \\
\hline SZ & -0.080 & 0.00 & -19.57 & $0.00^{* * *}$ \\
\hline $\mathrm{SZ}^{2}$ & -0.250 & 0.06 & -0.72 & 0.47 \\
\hline $\mathrm{OWN}_{\mathrm{i}}{ }^{2}$ & -0.170 & 4.35 & -0.56 & 0.56 \\
\hline $\mathrm{OWN}_{\mathrm{idv}}{ }^{2}$ & -0.090 & 8.77 & -0.65 & 0.52 \\
\hline $\mathrm{OWN}_{\mathrm{f}}{ }^{2}$ & 0.210 & 3.91 & 0.89 & 0.38 \\
\hline Adj. $R^{2}$ & 0.1902 & & & \\
\hline DW & 1.850 & & & \\
\hline
\end{tabular}

Note: ${ }^{* * *}=$ significant at $99 \%,{ }^{* *}=$ significant at $95 \%$.

Source: Authors' calculations.

The growth opportunity available to the firm is measured by the $\mathrm{M} / \mathrm{B}$ ratio. In the dividend yield model, sales growth is significant, whereas in the dividend payout model, sales growth is not, although the $\mathrm{M} / \mathrm{B}$ ratio is highly significant at 1 percent. It has a negative coefficient, which suggests that firms with an opportunity to expand operations tend to retain excess cash flows. As discussed earlier, larger firms usually need a higher cash flow than smaller firms to maintain their day-to dayoperations and thus maintain a certain level of cash. This is why firm size and the $M / B$ ratio have a negative impact on payouts: such firms save an excess cash flow by avoiding dividend payouts.

Ownership structure is highly significant with respect to the payout ratio, but has a negative coefficient, which implies that a high concentration of institutional ownership reduces dividend payouts, primarily because the firm's debts (loans) are securitized. Such institutions invest in some form of assets or reserves, which they maintain at the expense of low dividend payouts. Most banks invest their FCF in different types of assets to secure their liabilities and maintain their financial position in the market, 
thus avoiding any dividend payments. This variable is highly significant at 99 percent, although its square has no impact on the payout ratio.

Firms with a high concentration of shares held by family members or the management itself are likely to pay significantly fewer dividends. When this category of owners is compensated in the form of high salaries, it increases the firm's expenses such that its net earnings may be insufficient to pay dividends. Moreover, managers may be reluctant to distribute any FCF among shareholders because they would rather use it to invest in unprofitable projects (the agency problem). The squared term has no impact.

The third category of ownership structure - shares held by individual investors - has a negative and highly significant relationship with dividend payouts because most individuals prefer capital gains (which are tax-exempt) to dividends (which are subject to double taxation). Tax treatment, therefore, plays an important role for individuals making a decision regarding dividend payouts. The squared term of the independent variable has no impact on payouts. Finally, the DW statistic is 1.85 , which indicates the absence of first-order serial correlation.

Table 4 shows that there is no multicollinearity among the independent variables except in the case of ROA and ROE. This is very small, however, and may be because the same net income was used for specific years to calculate both; it does not affect our results significantly.

Table 4: Correlation matrix of independent variables, 2005-10

\begin{tabular}{lccrrrrrrr}
\hline & ROA & ROE & LEV & \multicolumn{1}{c}{ SG } & MBV & \multicolumn{1}{c}{ SZ } & OWN $_{\mathbf{i}}$ & OWN $_{\text {idv }}$ & OWN $_{\mathbf{f}}$ \\
\hline ROA & 1.000 & $0.261^{*}$ & -0.089 & -0.019 & 0.047 & 0.024 & 0.044 & -0.031 & -0.029 \\
ROE & $0.261^{*}$ & 1.000 & -0.022 & -0.055 & 0.028 & -0.051 & 0.001 & 0.002 & -0.002 \\
LEV & -0.089 & -0.022 & 1.000 & -0.015 & 0.007 & -0.045 & -0.066 & 0.038 & 0.047 \\
SG & -0.019 & -0.055 & -0.015 & 1.000 & -0.048 & 0.032 & 0.064 & -0.071 & -0.031 \\
$\mathrm{MBV}$ & 0.047 & 0.028 & 0.007 & -0.048 & 1.000 & -0.075 & -0.032 & -0.071 & 0.061 \\
$\mathrm{SZ}$ & 0.024 & -0.051 & -0.045 & 0.032 & -0.075 & 1.000 & 0.058 & -0.049 & -0.035 \\
$\mathrm{OWN}_{\mathrm{i}}$ & 0.044 & 0.001 & -0.066 & 0.064 & -0.032 & 0.058 & 1.000 & -0.012 & -0.041 \\
OWN $_{\text {idv }}$ & -0.031 & 0.002 & 0.038 & -0.071 & -0.071 & -0.049 & -0.012 & 1.000 & -0.031 \\
OWN $_{\mathrm{f}}$ & -0.029 & -0.002 & 0.047 & -0.031 & 0.061 & -0.035 & -0.041 & -0.031 & 1.000 \\
\hline
\end{tabular}

Source: Authors' calculations.

\section{Conclusion}

This study has used a dividend yield model and dividend payout model to measure the determinants of corporate dividend policy in an 
emerging market such as Pakistan. Much of the literature supports the validity of these models. The empirical evidence indicates the relevance of dividend models across capital markets, but especially so in emerging capital markets, where investors may react differently to changes in dividend rates or announcements. The study also helps us understand market behavior in this context. Given that dividend decisions are key to any corporation, firms must take every aspect of investor behavior into account.

Our results indicate that ROA and ROE have a positive and highly significant impact on dividend yield in Pakistan. These results are consistent with Grullon, Michaely, and Swaminathan (2002). Firms that have made a profit are more likely to announce dividends that year because they are certain about their prospects and ability to sustain future dividend payments (Ahmad \& Javid, 2009). Moreover, firms that generate enough operating cash flows have a higher net income. Higher profits imply stable earnings over time and larger FCFs that can be distributed as dividends (Nazir et al., 2010). Asghar et al. (2011) also support the positive relationship between dividend yield and a firm's earnings.

Firm size is significant, but has a negative effect in Pakistan. This indicates that, when making a decision about dividends, firms take their size into account. The larger the firm, the higher its liabilities, and the more likely it will retain any excess cash. This finding is consistent with AlMalkawi (2007) and Cohen and Yagil (2008). Larger firms may also retain funds for future business expansion, whereas smaller firms looking to increase market confidence will avoid omitting dividend payments. Asghar et al. (2011) draw a similar conclusion.

Sales growth has a significantly positive impact on dividends in Pakistan. This finding differs from other studies, which argue that sales growth is more likely to encourage firms to retain their FCFs (see Ahmad \& Javid, 2009; Afza \& Mirza, 2010). We find, however, that most Pakistani firms with greater opportunity for business expansion still manage to pay dividends out of their FCF, thus maintaining their market reputation. Myers and Majluf (1984) argue that firms with higher sales require extra funds to avail investments as the cheapest source of finance, that is, retained earnings. Additionally, mature companies have fewer chances to invest in high-growth projects because they have already grown to the optimum level of an average industrial business (Afza \& Mirza, 2011). Such companies have less incentive to expand and thus experience lower growth and incur less capital expenditure. 
Ownership concentration significantly affects dividend payouts. The empirical results show that institutional ownership has a significant impact on dividend payouts, with a negative coefficient, implying that a high concentration within institutions reduces dividend payouts. This result is consistent with Ahmad and Javid (2010) and Afza and Mirza (2010). However, our results contradict Faulkender and Wang (2006) and Aghion and Stein (2008), who argue that institutions prefer making dividend payments to avoid the agency problem. This does not hold true for our sample of Pakistani firms.

Family or management ownership structures imply that the firm is likely to pay smaller dividends. Ahmad and Javid (2010) and Afza and Mirza (2011) yield similar results on the premise that firms may earn negative incomes when they pay high salaries to family owners. Shares held by individual investors have an inverse and highly significant relationship with dividend payouts, consistent with Asghar et al. (2011). This result indicates that the tax treatment with respect to dividends plays an important role for individual investors (Miller \& Scholes, 1978).

Firm size is also highly significant with respect to dividend payouts. The larger the firm, the more likely it is to retain FCFs rather than giving out dividends in order to avoid any asset liquidation in case of debt repayment problems. Such firms generate funds internally to avoid costly external financing and usually defer gains (dividends) to their investors.

The growth opportunity available to firms was measured by the $M / B$ ratio and was found to have a negative impact which suggests that firms with the opportunity to expand their operations tended to retain excess cash flows to avoid costly external financing (Grullon \& Michaely, 2002). Thus, firms rely on internal financing because it is cheaper.

This study aims to help investors identify dividend-paying firms. The significant independent variables we have examined could help new investors establish which firm characteristics they should target: for example, profitability and high sales growth are likely to indicate dividend-paying firms for investors interested in dividend payments. Those interested in long-term gains may want to target firms with a high market-to book ratio and highly concentrated ownership structure.

Our findings could also help financial managers and investors make better decisions regarding dividend policy, and eventually maximize their returns. This includes identifying which significant factors affect dividend yield and payout ratios for firms in Pakistan, enabling them to design policies that enable dividend-smoothing behavior in the capital market. 


\section{References}

Afza, T., \& Mirza, H. H. (2010). Ownership structure and cash flows as determinants of corporate dividend policy in Pakistan. International Business Research, 3(3), 210-221.

Afza, T., \& Mirza, H. H. (2011). Do mature companies pay more dividends? Evidence from Pakistani stock market. Mediterranean Journal of Social Sciences, 2(2), 152-161.

Aghion, P., \& Stein, J. C. (2008). Growth versus margins: Destabilizing consequences of giving the stock market what it wants. Journal of Finance, 63(3), 1025-1058.

Ahmad, H., \& Javid, A. (2009). Dynamics and determinants of dividend policy in Pakistan (evidence from Karachi Stock Exchange nonfinancial listed firms). International Research Journal of Finance and Economics, 25, 148-171.

Ahmad, H., \& Javid, A. (2010). The ownership structure and dividend payout policy in Pakistan (evidence from Karachi Stock Exchange 100 index). International Journal of Business Management and Economic Research, 1(1), 58-69.

Al-Malkawi, H.-A. N. (2007). Determinants of corporate dividend policy in Jordan: An application of the tobit model. Journal of Economic and Administrative Sciences, 23(2), 44-70.

Asghar, M., Shah, S. Z. A., Hamid, K., \& Suleman, M. T. (2011). Impact of dividend policy on stock price risk: Empirical evidence from equity market of Pakistan. Far East Journal of Psychology and Business, 4(1), $45-52$.

Baker, M., \& Wurgler, J. (2004). A catering theory of dividends. Journal of Finance, 59(3), 1125-1165.

Bhattacharya, S. (1980). Nondissipative signaling structures and dividend policy. Quarterly Journal of Economics, 95(1), 1-24.

Cohen, G., \& Yagil, J. (2008). On the catering theory of dividends and the linkage between investment, financing and dividend policies. International Research Journal of Finance and Economics, 17, 33-39. 
Damodaran, A. (1989). The weekend effect in information releases: A study of earnings and dividend announcements. Review of Financial Studies, 2(4), 607-623.

DeAngelo, H., \& DeAngelo, L. (2006). The irrelevance of the MM dividend irrelevance theorem. Journal of Financial Economics, 79(2), 293-315.

DeAngelo, H., DeAngelo, L., \& Skinner, D. J. (2008). Corporate payout policy (Foundations and Trends in Finance, vol. 3). Boston, MA: Now Publishers.

Denis, D. J., \& Osobov, I. (2008). Why do firms pay dividends? International evidence on the determinants of dividend policy. Journal of Financial Economics, 89(1), 62-82.

Farinha, J. (2003). Dividend policy, corporate governance and the managerial entrenchment hypothesis: An empirical analysis. Journal of Business Finance and Accounting, 30(9-10), 1173-1209.

Faulkender, M., \& Wang, R. (2006). Corporate financial policy and the value of cash. Journal of Finance, 61(4), 1957-1990.

Gill, A., Biger, N., Mand, H. S., \& Shah, C. (2012). Corporate governance and capital structure of small business service firms in India. International Journal of Economics and Finance, 4(8), 83-92.

Grullon, G., \& Michaely, R. (2002). Dividends, share repurchases, and the substitution hypothesis. Journal of Finance, 57(4), 1649-1684.

Grullon, G., Michaely, R., \& Swaminathan, B. (2002). Are dividend changes a sign of firm maturity? Journal of Business, 75(3), 387-424.

Imran, K. (2011). Determinants of dividend payout policy: A case of Pakistan engineering sector. Romanian Economic Journal, 14(41), 47-60.

Jensen, M. C. (1986). Agency costs of free cash flow, corporate finance, and takeovers. American Economic Review, 76(2), 323-329.

Khang, K., \& King, T.-H. D. (2006). Does dividend policy relate to crosssectional variation in information asymmetry? Evidence from returns to insider trades. Financial Management, 35(4), 71-94. 
Kumar, J. (2006). Ownership structure and dividend payout policy in India. Journal of Emerging Market Finance, 5(1), 15-58.

Lintner, J. (1956). Distribution of incomes of corporations among dividends, retained earnings, and taxes. American Economic Review, $46(2), 97-113$.

Miller, M. H., \& Modigliani, F. (1961). Dividend policy, growth, and the valuation of shares. Journal of Business, 34(4), 411-433.

Miller, M. H., \& Scholes, M. S. (1978). Dividends and taxes. Journal of Financial Economics, 6(4), 333-364.

Modigliani, F., \& Miller, M. H. (1958). The cost of capital, corporation finance and the theory of investment. American Economic Review, 48, 261-297.

Moyen, N. (2004). Investment-cash flow sensitivities: Constrained versus unconstrained firms. Journal of Finance, 59(5), 2061-2092.

Myers, S. C., \& Majluf, N. S. (1984). Corporate financing and investment decisions when firms have information that investors do not have. Journal of Financial Economics, 13(2), 187-221.

Nazir, M. S., Nawaz, M. M., Anwar, W., \& Ahmed, F. (2010). Determinants of stock price volatility in Karachi Stock Exchange: The mediating role of corporate dividend policy. International Research Journal of Finance and Economics, 55, 100-107.

Renneboog, L., \& Szilagyi, P. G. (2008). Corporate restructuring and bondholder wealth. European Financial Management, 14(4), 792-819.

Rozeff, M. S. (1982). Growth, beta and agency costs as determinants of dividend payout ratios. Journal of Financial Research, 5(3), 249-259.

Skinner, D. J., \& Soltes, E. (2011). What do dividends tell us about earnings quality? Review of Accounting Studies, 16(1), 1-28. 